\title{
Tinjauan Hukum Islam Pada Edaran Pemerintah Dan MUI Dalam Menyikapi Wabah Covid-19 Setelah Pemberlakuan New Normal
}

\author{
Cholisa Rosanti \\ Fakultas Ekonomika dan Bisnis, Universitas Muhammadiyah Pekajangan Pekalongan \\ E-mail: feb@umpp.ac.id
}

\begin{abstract}
This study discusses the Covid-19 virus that is spreading in the world and its handling from the government and MUI after the implementation of new normal according to Islamic law. The government implements a large-scale social restrictions system (PSBB) or social distancing to break the chain of the spread of the covid-19 virus. The government has implemented new normal rules. MUI has issued a notice numbered Kep-1188 / DP-MUI / V / 2020 concerning new normalcy that will be applied by the government such as reopening places of worshipaccording to the health protocol. Nevertheless, this circular is a pros and cons for some people. The purpose of this study is to help the public understand whether the government and MUI circulars in tackling the plague after applying the new normal according to the Shari'a or actually contrary to Islamic Sharia. The research method is the study of literature literature with a normative approach and historical approach. The results of the study showed that the rules imposed by the government and MUI in dealing with the outbreak of Covid-19 pacsa new normal did not disregard Islamic law.
\end{abstract}

Keywords : Islamic law, covid-19, new normal

Saran sitasi: Rosanti, C. (2021). Tinjauan Hukum Islam Pada Edaran Pemerintah Dan MUI Dalam Menyikapi Wabah Covid-19 Setelah Pemberlakuan New Normal. Jurnal Ilmiah Ekonomi Islam, 7(01), 393-402. doi:http://dx.doi.org/10.29040/jiei.v7i1.2157

DOI: http://dx.doi.org/10.29040/jiei.v7i1.2157

\section{PENDAHULUAN}

Pemerintah dan bersama rakyat Indonesia sekarang telah berperang melawan wabah virus corona atau covid-19. Wabah covid-19 ini telah melanda berbagai negara di belahan dunia ini, baik di benua Eropa, benua Asia maupun di benua Amerika. Wabah penyakit virus corona ini telah membuat korban jiwa berjatuhan dengan jumlah ribuan jiwa. Menurut Abidinsyah dalam Indriya (2020), WHO pada tanggal 12 Maret 2020 telah menyatakan sebaran virus covid-19 sebagai pandemic. Tercatat 156 negara dan telah menginfeksi sebanyak 167.740 orang, meninggal 6.456 orang, dan sembuh 76.598 orang, sedangkan 5.811 orang dalam kondisi kritis.

Agresi covid-19 telah menghancurkan berbagai sendi kehidupan masyarakat lebih dari 212 negara. Pertumbuhan ekonomi setiap negara menjadi lesu, turun drastis dari target yang telah ditetapkan. Selain dalam bidang ekonomi, dampak dari pandemi covid19 yang sangat terasa oleh seluruh lapisan masyarakat beragama di berbagai negara termasuk di Indonesia adalah dalam bidang kehidupan beragama.

Diterapkannya kebijakan pemerintah tentang menjaga jarak sosial (social distancing) yang kemudian oleh Badan Kesehatan Dunia, WHO (World Health Organization) diganti dengan istilah menjaga jarak fisik (physical distancing), membuat tempattempat ibadah menjadi kurang difungsikan sehingga menjadi sepi. Physical distancing didefinisikan sebagai tindakan menjaga jarak fisik antar individu dengan jarak 1 meter dengan tujuan supaya setiap individu tetap dapat saling menguatkan dan berinteraksi diantara mereka, walaupun secara fisik terdapat jarak di antara mereka atau tidak bisa berdekatan. Dengan demikian, physical distancing tidak berarti bahwa kita mengisolasi diri, memutus hubungan sosial dengan orang yang kita cintai (World Health Organization, 2020).

Selanjutnya, Pemerintah Indonesia mengeluarkan PP 21 tahun 2020 tentang Pembatasan 


\section{Jurnal Ilmiah Ekonomi Islam, 7(01), 2021, 394}

Sosial Berskala Besar (PSBB) dalam rangka Percepatan Penanganan Corona Virus Disease (Covid-19). Sebagai negara terbesar yang berpenduduk muslim, kebijakan PSBB tentu bukanlah hal yang mudah untuk dilaksanakan, terutama apabila kebijakan tersebut dilihat dari sisi keagamaan, di mana kebijakan tersebut akan mensyaratkan terjadinya banyak perubahan di dalam pelaksanaan ritual keagamaan sehari-hari.

Selanjutnya, pemerintah mengeluarkan Surat Edaran Menteri Agama Nomor 6 Tahun 2020 tentang Panduan Ibadah Ramadan dan Idul Fitri 1 Syawal $1441 \mathrm{H}$. MUI juga telah mengeluarkan edaran untuk tidak melaksanakan ibadah di masjid, salat Jumat diganti salat zuhur dan dilaksanakan di rumah masingmasing hingga berakhirnya pandemi covid-19 ini. di Tengah Pandemi Covid-19 suasana Ramadhan tahun ini terasa sangat berbeda dari tahun-tahun sebelumnya. Masjid-masjid yang biasanya ramai dengan berbagai kegiatan ibadah dan aktivitas sosial seperti shalat Jum'at, shalat Fardhu berjamaah, shalat Tarawih, ceramah keagamaan, buka bersama, I'tikaf, Sanlat, pengumpulan zakat, infak dan sedekah, dan sebagainya, sekarang menjadi sepi total, karena menurut Surat Edaran Menteri Agama tersebut seluruh kegiatan itu dipindahkan ke rumah masingmasing demi mempercepat putusnya mata rantai penyebaran wabah Copid-19 (Kementerian Agama RI, 2020).

Saat ini muncul istilah "new normal" seiring dengan pandemik coronavirus disease 19 yang dikenal Covid-19. Pasalnya, tidak ada yang dapat mengklaim kapan vaksin Covid-19 akan ditemukan. Sementara kelangsungan hidup normal sangat dibutuhkan. Sehingga timbul istilah new normal, termasuk di Indonesia (Pragholapati, 2020). Penggunaan istilah new normal telah dijumpai sejak beberapa tahun lalu. Istilah new normal digunakan untuk penemuan teknologi tentang databases (Fagin, 1977).Terdapat pula penggunaan new normal untuk masalah keuangan, pekerjaan, dan layanan pemerintah daerah (Martin, Levey, \& Cawley, 2012) dan new normal lainnya.

Belakangan new normal timbul berkenaan dengan pandemic covid-19. Ditegaskan bahwa new normal adalah istilah yang dihasilkan dari adaptasi proses sementara dalam pandemi covid-19, di mana manusia akan memiliki kebiasaan baru dari pembelajaran dan proses adaptasi setelah pandemi Covid-19 (Pragholapati, 2020). Pemerintah akan menerapkan sejumlah aturan di rumah ibadah saat periode new normal dengan tujuan menjaga masyarakat dari ancaman covid-19. Selain itu peraturan ini diharapkan kegiatan ibadah masyarakat bisa kembali berjalan normal, namun dengan ditambah menerapkan protokol kesehatan dan berbagai aturan untuk mencegah penularan virus covid-19 seperti menjaga jarak saat sholat.

Majelis Ulama Indonesia (MUI) telah menerbitkan maklumat mengenai kenormalan baru yang akan diterapkan oleh Pemerintah. Maklumat tersebut bernomor Kep-1188/DP-MUI/V/2020. Para tokoh agama dan masyarakat pun dalam menyikapi Surat Edaran itu terbagi menjadi dua kelompok, yang pro dan kontra. Terlebih laporan Badan Nasional Penanggulangan Bencana (BNPB) menyebutkan bahwa pandemi covid-19 masih belum dapat diatasi. Dengan jumlah kasus terinfeksi covid-19 yang relatif masih tinggi, tentunya pelaksanaan new normal ini berpotensi menciptakan klaster baru covid-19. Selain itu, aturan sholat dengan shaf berjarak menimbulkan polemik pada umat Islam. Imbauan tersebut dinilai menyalahi hadis Rasulullah Muhammad SAW yang menganjurkan merapatkan shaf sebagai bagian dari kesempurnaan shalat.

Inilah masalah yang akan dikaji dalam artikel ini, apakah edaran pemerintah berupa lockdown dan PSBB atau social distancing sesuai syariat nabi Shallallahu 'Alaihi Wasallam dalam menanggulangi wabah?. Dan apakah edaran dari MUI untuk melaksanakan salat dengan shaf berjarak dan menggunakan masker tidaklah menyalahi syariat Islam?. Dengan demikian, maka tujuan pengkajian ini adalah berusaha untuk membantu memberikan pemahaman bagi masyarakat tentang wajibnya taat pada edaran pemerintah dan fatwa MUI. Selain itu, juga memberikan pemahaman bahwa apa yang telah menjadi edaran pemerintah dan MUI juga telah pernah disosialisasikan oleh nabi Shallallahu 'Alaihi Wasallam bersama para sahabatnya, serta tidaklah melanggar syariat Islam.

Beberapa penelitian terdahulu yang relevan tersebut di antaranya adalah penelitian yang dilakukan oleh Muhammad Tahir tentang nalar agama dan pandemi covid-19. Jenis penelitian adalah kualitatif dengan pendekatkan teologis. Tahir, dalam penelitiannya mengungkapkan bahwa menyikapi pandemi covid-19 dengan mengikuti protokol kesehatan yang dianjurkan oleh para ahli serta mematuhi himbauan para ulama yang teruji 


\section{Jurnal Ilmiah Ekonomi Islam, 7(01), 2021, 395}

kealimannya. Jika ahli medis/kesehatan, pada ulama satu suara begitu juga dengan pemerintah maka bagi orang awam adalah taat dan patuh pada anjuran tersebut. menghindari kerumunan untuk keselamatan bersama tentu lebih baik daripada memaksakan ibadah mahdah yang mengancam keselamatan bersama (Tahir, 2020).

Kedua, penelitian yang dilakukan oleh Indriya. Ini merupakan salah satu hasil penelitianyang secara spesifik menghubungkan antara pandemi covid-19 dengan salah satu aspek ajaran agama Islam, yaitu tentang konsep tafakkur dalam Al-Qur'an. Indriya, dalam penelitian kualitatifnya ini menggunakan metode deskriptif dengan pendekatan literature review. Tafakkur, dalam penelitian ini, tidak sekedar difahami sebagai suatu upaya berfikir untuk menjembatani persepsi dan konsepsi dari kehidupan fana ini ke kehidupan akhirat yang kekal, dan dari makhluk ke Penciptanya, yaitu Allah Swt.; melainkan sebuah upaya berfikir mendalam yang melampaui hidup ini ke wilayah lebih luas, yakni akhirat, dan melewati kedangkalan materialisme menuju horizon lebih dalam, yaitu "ruh" yang menjadi motivator bagi seluruh kegiatan eksternal dan internal ummat Islam. Secara spesifik, penelitian yang dilakukan Indriya bertujuan untuk men-tafakkuri peristiwa Pandemi covid-19 dengan menggunakan perspektif Pendidikan Islam. Hasil penelitian ini menunjukkan bahwa tafakkur covid-19 menurut perspektif Pendidikan yang dilakukan melalui physical distancing, yaitu mengisolasi daerah atau individu yang terkena wabah, bersabar; berbaik sangka (husnu al-zhan) dan berikhtiar (ikhtiyar), dan banyak berdoa (Indriya, 2020).

Ketiga, penelitian yang dilakukan oleh Mukharom dan Havis Aravik tentang kebijakan Nabi Muhammad Shallallahu 'Alaihi Wasallam dalam menangani wabah penyakit menular dan implementasinya dalam konteks menanggulangi wabah covid-19. Penelitian ini lebih kepada contoh penanggulangan nabi terkait wabah yang terjadi di zamannya, adapun hasilnya menunjukkan bahwa lockdown dan social distancing adalah cara yang tepat dalam menangani wabah dan juga itulah yang dijalankan oleh nabi tatkala wabah menjangkiti kota Madinah (Mukharom dan Aravik, 2020).

Keempat, penelitian yang dilakukan Arifin, dkk (2020) tentang proteksi diri saat pandemi covid-19 Berdasarkan Hadits Shahih. Penelitian ini menggunakan pendekatan kualitatif dengan menerapkan metode deskriptif analitis. Data dikumpulkan dengan menggunakan teknik studi literatur dan studi dokumentasi, lalu data dianalisis dengan menggunakan pendekatan dan teknik analisis kualitatif. Hasil penelitian menunjukkan bahwa berdasarkan Hadits-Hadits shahih ada serangkaian prosedur hirarki yang harus dilakukan oleh setiap individu untuk memproteksi diri dan masyarakatnya ketika terjadi pandemi covid-19 yang jika seluruh langkah proteksi diri itu dilakukan dengan baik akan mampu memutus mata rantai penyebaran covid-19 dan berbagai jenis virus lainnya yang memiliki kesamaan karakter dalam proses penyebarannya. Langkah-langkah itu dimulai dari menjauhkan diri dari wabah, senantiasa berdo'a, tawakal kepada Allah, menggunakan masker setiap saat, senantiasa mencuci tangan, mengkonsumsi makanan dan minuman yang halal, sehat, lezat, dan bergizi, dan optimis bahwa Allah akan mengakhirinya. Penelitian ini menyimpulkan bahwa dalam Hadits-Hadits shahih terdapat protap untuk memproteksi diri dari berbagai wabah penyakit yang secara empiris sudah teruji kehandalannya.

Kelima, penelitian yang dilakukan oleh Rajab, dkk (2020) tentang tinjauan hukum islam pada edaran pemerintah dan MUI dalam menyikapi wabah covid19. Metode penelitian yang digunakan adalah kajian literatur kepustakaan dengan pendekatan normatif dan didukung dengan pendekatan historis. Hasil penelitian menunjukkan bahwa aturan yang diberlakukan pemerintah dan MUI dalam menangani wabah covid19 sama sekali tidak menyelisihi syariat Islam. Penelitian ini sudah sejalan dalam pengkajian di artikel ini, namun ada beberapa kebaruan yang akan kami kaji seperti tinjauan hukum islam setelah pemberlakuan new normal yang ditetapkan pemerintah.

Studi-studi yang telah dideskripsikan di atas diketahui bahwa fokusnya berbeda dengan yang dilakukan penulis dalam riset ini, yaitu tinjauan hukum islam pada edaran pemerintah dan MUI dalam menyikapi wabah covid-19 setelah diberlakukan new normal. Menggunakan kajian literatur kepustakaan dengan pendekatan normatif dan pendekatan historis, penelitian ini fokus untuk membantu memberikan pemahaman kepada masyarakat yang masih awam terhadap edaran pemerintah dan fawa MUI setelah adanya new normal yang diterapkan oleh pemerintah. Semua cara penanggulangan yang diedarkan pemerintah atau MUI sendiri telah ada landasannya 


\section{Jurnal Ilmiah Ekonomi Islam, 7(01), 2021, 396}

dari agama tanpa harus mengaitkan masalah keimanan ini rendah atau tinggi karena takut dengan wabah covid-19 yang menimpa.

\section{METODE PENELITIAN}

Metode Penelitian yang digunakan dalam penelitian ini menggunakan metode penelitian kepustakaan dengan pendekatan normatif dan pendekatan historis. Pengumpulan data yang ditempuh dalam penelitian ini dengan melakukan studi kepustakaan, sumber data penelitian berasal dari sumber-sumber yang telah terkumpul dari perpustakaan. Studi kepustakaan yang dimaksud adalah penelitian yang sumber-sumber datanya terdiri atas bahan-bahan tertulis yang telah dipublikasikan dalam bentuk buku, jurnal ilmiah, surat kabar, majalah dan lain-lain.

\section{HASIL DAN PEMBAHASAN}

\subsection{Sikap Menghadapi Virus Corona}

Islamic Worldview, cara pandang Islam dalam melihat segala hal yang terjadi di dunia, sudah dipandu di dalam kitab suci Alquran, terdapat pada Surat alBaqarah [2]: 155-157.

"Dan sungguh akan Kami berikan cobaan kepada kamu, dengan sedikit ketakutan, kelaparan, kekurangan harta, jiwa dan buahbuahan. Dan berikanlah berita gembira kepada orang-orang yang sabar, (yaitu) orang-orang yang apabila ditimpa musibah, mereka mengucapkan: "Inna lillahi wa inna ilaihi raji'un".Mereka itulah yang mendapat keberkatan yang sempurna dan rahmat dari Rabb mereka dan mereka itulah orangorang yang mendapat petunjuk." (Departemen Agama, 2004).

Merujuk pada ayat tersebut, dalam konteks sekarang, dengan adanya virus corona merupakan salah satu cobaan. Semua orang dibuat takut dan khawatir oleh penyebaran virus covid 19 ini. Oleh sebab itu, sikap yang diambil adalah meyakini bahwa virus adalah makhluk Allah, tunduk dan taat atas perintah Allah Swt. Dengan demikian, manusia diharuskan kembali kepada jati dirinya yaitu ada Yang Maha Kuasa dibalik semua kejadian di muka bumi ini. Oleh karenanya, kita berlindung dari wabah ini kepada Allah sebelum kita berlindung kepada kemampuan diri kita sendiri atau kemampuan makhluk lainnya. Ingatlah bahwa Allah adalah sebaik-baiknya pelindung dan sebaik-baiknya penjaga. Allah berfirman:

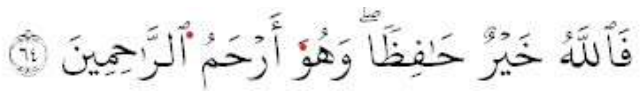

"Maka Allah adalah sebaik-baik Penjaga dan Dia adalah Maha Penyanyang diantara para penyanyang”(QS Yusuf, Ayat 64).

Berlindung kepada Allah ini bisa dilakukan dengan senantiasa membaca doa-doa pelindung yang bersumber dari Al-Qur'an. Salah satu contohnya yang sudah diajarkan Rasulullah Saw untuk dilafadzkan di setiap pagi dan sore berikut ini:

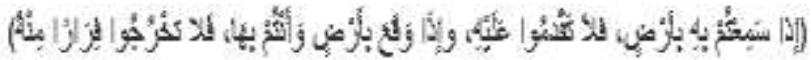

"Bismillahilladzi laa yadhurru maasmihi, say'un fil ardhi walafissamaai wahuwa samiul'alim."

"Dengan nama Allah yang apabila disebut, segala sesuatu dibumi dan langit tidak berbahaya. Dialah maha mendengar dan maha mengetahui).

Barang siapa yang membaca dzikir tersebut 3x dipagi dan petang. Maka tidak akan ada bahaya yang memudharatkannya (HR. Abu Dawud dan Tirmidzi).

Sikap kedua adalah berikhtiar. Di samping berlindung kepada Allah, tentunya sebagai seorang manusia kita juga harus berikhtiar dengan melakukan usaha-usaha pencegahan agar virus ini tidak menular kepada diri kita atau kepada orang-orang yang kita sayangi. Ikhtiar ini bisa dilakukan dalam skala individu maupun skala berjamaah (Jabbar, 2020a).

Ikhtiar dalam skala individu dilakukan dengan mengikuti cara-cara yang dianjurkan oleh para ahli dalam bidang ini, seperti rutin menjaga kesehatan, rutin mencuci tangan, rutin memakan dari makananmakanan yang baik, rutin memakai masker dikeramaian, serta menghindari keluar rumah dan berkumpul di tempat keramaian bila tidak diperlukan. Adapun ikhtiar dalam skala berjamaah, maka bisa dilakukan dengan cara melakukan pencegahanpencegahan agar virus ini tidak merambah ke skala yang lebih luas lagi seperti melakukan isolasi kepada mereka-mereka yang terkena virus atau mereka yang tercurigai terkena virus.

Ikhtiar ini hendaklah dilakukan oleh pihak-pihak yang berwenang. Dalam kisah Umar bin Khattab berikhtiar menghindarinya, serta Amr bin Ash berikhtiar menghapusnya. Istilah saat ini dan sedang kita lakukan adalah melakukan "social distancing",dilansir dari The Atlantic, tindakan yang bertujuan untuk mencegah orang sakit melakukan 
kontak dalam jarak dekat dengan orang lain untuk mengurangi peluang penularan virus. Artinya juga sementara waktu menjauhi perkumpulan, menghindari pertemuan massal, dan menjaga jarak antar manusia (Indriya, 2020). Hal ini berdasarkan makna hadis Nabi shallallahu alaihi wasallam yang berbunyi:

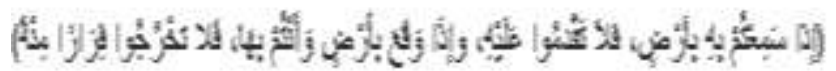

"Apabila kalian mendengar tentangnya (wabah penyakit) di sebuah tempat, maka janganlah kalian masuk ke dalamnya, dan bila kalian berada di dalamnya, maka janganlah kalian keluar daripadanya sebagai bentuk lari daripadanya”. (HR.Bukhari dan Muslim).

Sikap ketiga adalah Sabar dan tawakkal. Di dalam sebuah hadis riwayat Imam Bukhari diceritakan, suatu kali Aisyah bertanya kepada Nabi SAW tentang wabah penyakit. Rasulullah SAW bersabda,

"Wabah penyakit itu adalah orang-orang yang DIA kehendaki. Allah menjadikannya sebagai rahmat bagi orang-orang yang beriman. Jika terjadi suatu wabah penyakit, ada orang yang menetap di negerinya, ia bersabar, hanya berharap balasan dari Allah Swt. Ia yakin tidak ada peristiwa yang terjadi kecuali sudah ditetapkan Allah. Maka, ia mendapat balasan seperti mati syahid."

Setelah melakukan berbagai ikhtiar yang ada, maka pada akhirnya semua kita serahkan kepada Allah. Kita tawakkalkan diri kita kepadaNya. Karena hidup dan mati kita sebagai seorang hamba semua berada di tanganNya. Hadits hasan shahih yang diriwayatkan oleh Imam Tirmidzi pada Hadits nomor 2266 tentang tawakal itu memiliki makna yang sangat dalam. Terkadang ada beberapa kelompok masyarakat yang salah memahaminya. Makna yang paling benar dari Hadits itu adalah bahwa apabila individu atau masyarakat sudah melakukan tawakalnya kepada Allah dengan penuh kesungguhan dari lubuk hatinya yang terdalam dan bersandar kepada Allah dengan penyandaran yang sepenuhnya dalam mengambil kemaslahatan seperti diberikan kesehatan dan rezeki dalam bentuk materi yang banyak dan menolak bahaya atau kemadharatan seperti dihindarkannya dari pandemi covid-19 serta melakukan berbagai upaya relevan yang dapat menjadi sebab-sebab tercapainya sebuah keinginan, maka akan datang rezeki yang diinginkan kepadanya baik dalam bentuk kesehatan, materi, maupun dalam bentuk dihindarkannya dari pandemi covid-19 (Arifin, dkk 2020).

Dalam kontek bertawakal yang benar, usaha itu harus ada walaupun dalam wujudnya yang sangat sederhana, sebagaimana datangnya rezeki kepada burung dengan sekedar terbang pergi di pagi hari dari, dan pulang di sore hari ke, sarangnya. Mahluk Allah Swt. yang bernama manusia yang bertakwa dan bertawakal sepenuhnya kepada Allah telah mendapat jaminan dari Allah untuk mendapatkan kecukupan atas apa yang dibutuhkannya, sebagaimana Allah kemukakan dalam Al-Qur'an Surat Al-Thalaq ayat 3 bahwa siapa pun yang tawakal kepada Allah, maka Allah akan memberikan kecukupan atas keperluannya (Kementerian Agama RI, 2000).

\subsection{Hukum Islam Terkait Edaran Pemerintah}

Indonesia tidak mengambil kebijakan lockdown untuk mengantisipasi virus corona. Pemerintah lebih memilih kebijakan social distancing atau pembatasan sosial, dari sisi penanganan, lockdown memang dianggap lebih cepat. Tetapi, lockdown memberi dampak yang besar khususnya di ekonomi, karena kalau lockdown kegiatan ekonomi lumpuh sama sekali, tida ada aktivitas, kondisi masyarakat Indonesia 60-70 pekerja di Indonesia merupakan pekerja informal. Mereka kebanyakan mendapatkan pendapatan secara harian, sehingga jika sistem ini diterapkan merekalah yang akan pertama kali mendapatkan dampak besar dari sistem ini (Mukharom dan Aravik, 2020). Namun, jika ditinjau dalam perpekstif sejarah dan syariat Islam apakah sistem social distancing atau pembatasan sosial ini tidaklah menyalahi syariat Islam?

Mengutip dari buku Murtadha Muthahhari bahwa Ibn Abil Hadid menyebutkan bahwa Umar bin Khatthab berencana melakukan perjalanan ke Syam (Suriah). Lalu diberitahu bahwa tersebar wabah penyakit di Syam. Maka Umar membatalkan untuk memasuki daerah Syam. Abu Ubaidah bin Jarrah tidak setuju dengan keputusan tersebut dengan alasan lari dari takdir Tuhan. Lalu Abdurrahman bin Auf meriwayatkan hadis Rasulullah saw melarang keluarnya penduduk dari satu kota yang terjangkit wabah atau masuknya orang yang berada dari luar (Muthahhari, 2012).

Larangan nabi Shallallahu 'Alaihi Wasallam dalam hadis di atas adalah menggambarkan sebuah 


\section{Jurnal Ilmiah Ekonomi Islam, 7(01), 2021, 398}

sistem pelarangan bagi masyarakat yang terkena wabah atau pun tho'un untuk keluar dari daerahnya begitu pun bagi pendatang dari luar dilarang untuk masuk ke daerah yang terjangkiti wabah. Larangan inilah yang kita sebut sebagai sistem lockdown di zaman ini. Namun, ada beberapa hukum permasalahan terkait hadis ini yang juga harus dijawab permasalahannya. Di antaranya, apakah hukum larangan pada hadis tersebut adalah mutlak haram bagi seseorang untuk keluar dari lokasi wabah?

Para ulama berbeda pendapat perihal tersebut, yaitu larangan keluar dari lokasi yang teridentifikasi wabah. Namun, banyak di antara mereka rahimahumullah memberikan pemahaman bahwa larangan nabi Shallallahu 'Alaihi Wasallam tidaklah bersifat mutlak, namun larangan tersebut berlaku kepada orang yang ingin lari dari wabah. Sebagaimana firman Allah swt. Dalam Q.S. Al-Baqorah/2: 243 yang artinya; "Apakah kamu tidak memperhatikan orangorang yang ke luar dari kampung halaman mereka, sedang mereka beriburibu (jumlahnya) karena takut mati; maka Allah berfirman kepada mereka: 'Matilah kamu'. Kemudian Allah menghidupkan mereka. Sesungguhnya Allah mempunyai karunia terhadap manusia tetapi kebanyakan manusia tidak bersyukur." Dalam Tafsir Ad-Durr Al-Mantsur. 'Ibnu Abbas berkata: "Mereka berjumlah 4000 orang. Mereka keluar karena lari dari tho'un (wabah penyakit menular). Mereka berkata: 'Kami akan mendatangi sebuah negeri yang tidak ada kematian'. Setelah mereka sampai di sebuah perkampungan Allah mematikan mereka semua. Lalu datang seorang nabi berdoa agar Allah menghidupkan kembali mereka untuk menyembah Allah, lalu Allah menghidupkan mereka (Suyuti, 1432).

Adapun Ibnu Hajar rahimahullah memberikan rincian yang baik pada masalah ini, dimana Ibnu Hajar membaginya menjadi tiga keadaan (Ibnu Hajar, 1379 H) :

a. Jika mereka keluar dengan tujuan lari dari wabah maka ini adalah larangan sebagaimana yang disebutkan dalam hadis.

b. Adapun jika dia keluar dengan tujuan yang lain bukan lari dari wabah seperti bekerja dan selainnya, maka ini tidak termasuk dalam larangan dan ini adalah kesepakatan yang disebutkan oleh imam An-Nawawi tentang bolehnya keluar dengan tujuan bukan untuk lari dari wabah.

c. Keluar dengan niat untuk bekerja, dan masuk di dalamnya niat untuk selamat dari wabah, maka keadaan ini para ulama berbeda pendapat, adapun Ibnu Hajar rahimahullah memandang masalah ini sebagai alasan yang diperbolehkan dan kata beliau adalah mazhab dari Umar bin Khattab ra.

Menyikapi pandemi covid-19 yang penyebarannya sangatlah cepat, maka kembali kepada manusia untuk memilih dan menentukan takdirnya. Bila merujuk kepada petunjuk agama maka yang dianjurkan adalah menghindar, menjauh dari wabah Pandemi covid-19. Berjangkitnya penyakit wabah merupakan takdir Allah. Bila menghindar sehingga terbebas dari wabah, ini juga takdir Allah. Karenanya jangan hanya saat petaka terjadi, kita berkata, "itu takdir Allah. Ucapkanlah juga pada saat kita lepas dari wabah tersebut (Shihab, 2006). Oleh karena itu, sistem atau cara yang paling baik untuk melawan wabah saat ini, selain dari mengembalikan semuanya kepada Allah Ta'ala adalah juga dengan mengaplikasikan sistem lockdown yang sesuai edaran pemerintah. Berusaha untuk sementara tidak terlalu sering berkumpul sampai pandemi covid-19 ini berakhir.

\subsection{Hukum Social Distancing Menurut Agama}

Selain dari lockdown di antara edaran pemerintah adalah dengan mengaplikasikan sistem pembatasan sosial berskala besar (PSBB) atau juga disebut social distancing. Namun, apakah sistem ini tidaklah menyalahi aturan agama? Fenomena penyebaran covid-19 yang cepat ini direaksi oleh WHO dengan membuat formulasi social distancing yaitu menjaga jarak sosial dalam hubungan bermasyarakat, setidaknya untuk menahan penyebaran Covid-19 antar warga masyarakat. Penggunaan istilah ini menuai kontroversi di kalangan para ahli dan praktisi sosial. Istilah social distancing dipandang sebagai sebuah jarak yang menghilangkan jarak fisik (phisycal distancing), sekaligus menutup ruang sosial kemasyarakatan. Konsekuensi penggunaan istilah social distancing menjadi meluas dan melebar dalam skala hubungan sosial yang melibatkan mental yang terisolasi oleh adanya jarak. Tidak hanya sekedar fisik yang berjarak, tetapi juga kehidupan sosial yang lama berkembang di masyarakat harus tertutup ruangnya oleh jarak sosial.

WHO kemudian merevisi formulanya dari social distancing menjadi physical distancing, yaitu jarak fisik yang harus dijaga ketika berhubungan dengan orang lain. Istilah ini digunakan untuk menghilangkan (baca: menghindari) mindset adanya pembatasan ruang sosial dalam kehidupan sosial kemasyarakatan. Physical distancing tidak menghilangkan ruang sosial 
yang selama berjalan dan berkembang di tengah masyarakat. Penggunaan istilah ini dapat diterima oleh para ahli dan praktisi sosial. Namun masyarakat sudah terlanjur menggunakan istilah social distancing sebagai upaya pencegahan penyebaran covid-19. WHO membuat formula physical distancing ketika berkomunikasi atau berhubungan dengan orang dengan jarak satu meter.

Hukum social distancing sendiri jika ingin dikaji dalam sisi hukum Islam, maka social distancing bisa menjadi wajib atau sunah, jika memiliki kemaslahatan untuk ad-daruryah al khomsa (menjaga agama, jiwa, akal, keturunan dan harta) pada manusia. Contohnya ketika seseorang telah terindikasi terpapar virus covid19 ataukah masih dalam keadaan pengawasan, maka dengan berdiam diri atau mengarantina dirinya atau tidak keluar dan tidak menegur orang lain adalah hal wajib baginya. Adapun jika keluar dari rumah maka kemungkinan besarnya bisa memberikan penularan kepada yang lain, dan pada saat itu pula para ulama menilai makruh dan bahkan bisa sampai kepada keharaman karena telah memberikan kemudaratan pada orang lain.

Berkaitan dengan persoalan Physical Distancing ini, renungkanlah Hadis Rasulullah Saw yang dikutip dalam kitab Almuwatta' Imam Malik:

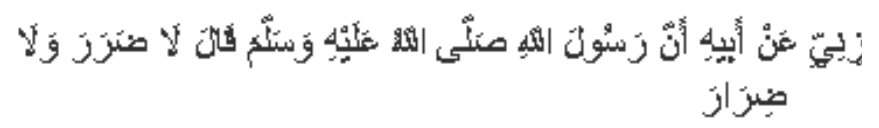

Telah menceritakan kepadaku Yahya dari Malik dari 'Amru bin Yahya Al Muzani dari Bapaknya bahwa Rasulullah Shalla Allahu 'alaihi wa sallam bersabda: "Tidak boleh membuat kemudharatan pada diri sendiri dan membuat kemudharatan pada orang lain."

Dalil yang kedua apa yang dilakukan oleh nabi Shallallahu 'Alaihi Wasallam dimana Rasulullah saw. tidak bersalaman untuk menerima baiat dari orang yang terkena penyakit menular kusta. Dari 'Amr bin Asy-Syarid dari bapaknya, beliau berkata;

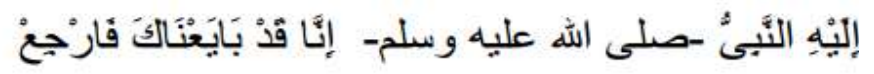

"Dahulu ada utusan dari Tsaqif ada yang terkena kusta. Maka nabi Shallallahu 'Alaihi Wasallam mengirim pesan, "Sungguh kami telah menerima baiat Anda (tidak perlu bersalaman), maka pulanglah." (Hajjaj, 1412).
Pada hadis tersebut apa yang dilakukan nabi Shallallahu 'Alaihi Wasallam dengan menolak untuk berjabat tangan dan hanya menerima baiat dari salah seorang sahabat adalah salah satu cara untuk membantu terputusnya penyebaran dari wabah. Berjabat tangan bukanlah hal yang terlarang, namun dia adalah syariat dan adab yang diajarkan dalam Islam. Akan tetapi, jika syariat tersebut ketika dilakukan menimbulkan kemudaratan maka pengaplikasiannya menjadi makruh bahkan bisa menjadi terlarang.

Pada masa sekarang, silahkan diperhatikan hadis tersebut. Kita tidak boleh membahayakan diri sendiri dan waspada agar tidak tertular oleh virus Corona dengan cara melaksanakan anjuran pemerintah dan arahan para ahli kesehatan, dan tidak boleh membahayakan orang lain dengan cara tidak keluar rumah dan karantina sendiri bagi orang sakit dan dianggap ODP (orang dalam pengawasan), PDP (pasien dalam pengawasan), atau bahkan positif Corona.

\subsection{Fatwa MUI tentang Wabah Covid-19 Setelah Pemberlakuan New Normal dan Penjabarannya dalam Tinjauan Syariat}

Kementerian Agama menerbitkan Surat Edaran (SE) nomor 15 tahun 2020 tentang Panduan Penyelenggaraan Kegiatan Keagamaan di Rumah lbadah Dalam Mewujudkan Masyarakat Produktif dan Aman Covid-19 di Masa Pandemi. Sebelumnya guna memutus rantai penularan virus corona (Covid-19) pemerintah meminta masyarakat untuk beribadah di rumah. Setelah terdapat instruksi memasuki tatanan kenormalan baru (new normal), Kemenag membuat panduan. Selain itu, Komisi Fatwa Majelis Ulama Indonesia (MUI) juga mengeluarkan Fatwa Nomor 31 Tahun 2020 tentang Penyelenggaraan Salat Jumat dan jemaah untuk mencegah Penularan Wabah Covid19. Untuk mencegah penularan covid-19, tempat ibadah pun harus disertai dengan protokol kesehatan yang harus dipatuhi setiap jemaah.

Ketentuan hukum yang mesti diperhatikan baik oleh pengurus masjid atau jemaah ialah perenggangan saf ketika salat berjamaah. Dalam fatwa tersebut dijelaskan apabila meluruskan dan merapatkan saf pada salat berjemaah merupakan keutamaan dan kesempurnaan berjamaah. Salat berjemaah dengan saf yang tidak lurus dan tidak rapat hukumnya tetap sah tetapi kehilangan keutamaan dan kesempurnaan jamaah. 


\section{Jurnal Ilmiah Ekonomi Islam, 7(01), 2021, 400}

Tentu tidak diragukan bahwa rapatnya shaff adalah kesempurnaan shalat yang diperintahkan oleh Nabi shallallahu álaihi wasallam. Nabi bersabda :

"Dan rapatkanlah shaff" (HR Al-Bukhari no 719).

Abidin (2020) menyatakan bahwa Nabi juga menyuruh untuk menutup celah dan kerenggangan, Nabi bersabda :

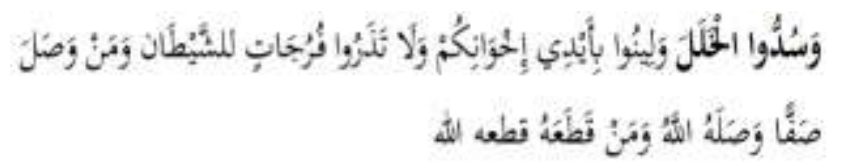

"Tutuplah celah, lembutlah kepada tangantangan saudara-saudara kalian dan janganlah kalian menyisakan celah-celah bagi syaitan. Barang siapa yang menyambung shaff maka Allah menyambungnya, dan barang siapa yang memutuskan shaff maka Allah akan memutuskannya" (HR Abu Daud no 672 dan dishahihkan oleh Al-Albani di As-Shahihah no 743).

Namun karena kondisi yang mengkhawatirkan dengan adanya wabah covid-19, sehingga diatur perenggangan saf ketika salat berjamaah jarak hingga lebih dari satu meter. Lantas apa hukumnya?

Adapun hukumnya maka sebagai berikut (Abidin, 2020) :

Pertama : Jika kerenggangan tersebut tidak mengeluarkan dari hukum shaff, dalam artian meskipun renggang akan tetapi masih dianggap shaff maka berarti makmum hanya meninggalkan perkara yang disepakati tidak membatalkan shalat. Hal ini karena para mayoritas ulama berpendapat bahwa merapatkan shaff hukumnya adalah sunnah dan tidak wajib.

Kedua : Jika kerenggangan sampai dianggap memutuskan shaff, maka para ulama juga memandang bahwa hal ini tidaklah membatalkan shalat. Dalam fatwa MUI disebutkan bahwa untuk mencegah penularan wabah covid-19, penerapan physical distancing saat salat jemaah dengan cara merenggangkan saf hukumnya boleh, salatnya sah dan tidak kehilangan keutamaan berjemaah karena kondisi tersebut sebagai hajat syariyyah (Herlambang, 2020).

Dalam fatwa MUI itu juga mengatur soal penggunaan masker saat salat. Jemaah harus menggunakan masker yang menutup hidung saat salat hukumnya boleh dan salatnya sah karena hidung tidak termasuk anggota badan yang harus menempel pada tempat sujud saat salat. Menurut Al Syairāzī (1412H) bahwa hukum menutup wajah saat salat adalah makruh. Oleh sebab itu, dilarang dari perbuatan tersebut ketika dalam salat. Kecuali jika ia menguap saat salat, maka dianjurkan baginya untuk menutup mulutnya, karena adanya وَتَرَاصُّوا l untuk itu (Al Khaț̣ābī, 1932). Menutup muıu sadı salat hukumnya adalah makruh kecuali ada hajat syariyyah. Sebagaimana ditegaskan dalam sebuah hadis yang diriwayatkan dari AbūHurairah radhiallahu 'anhu, beliau berkata;

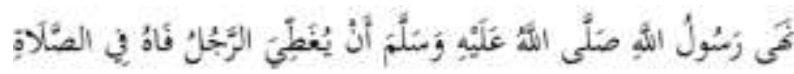

Artinya: "Rasulullah shallallahu 'alaihi wa sallammelarang seseorang menutup mulutnya ketika shalat." (Muhammad Ibn Yazīd Abū Abdillah Al Quzwainī).

Imam Abū Dāud dalam kitabnya Sunan Abī Dāud menjelaskan hadis ini menunjukkan bahwa hukum asal dalam salat adalah tidak menggunakan penutup. wajah, meskipun kata beliau tidak mengapa bagi seseorang menggunakan penutup wajah jika ada tuntutan hajat yang mengharuskan untuk menggunakannya (Syandri dan Akbar, 2020).

Jadi hukum asal menggunakan penutup mulut (masker) ketika salat adalah makruh tanzih yaitu makruh yang tidak membatalkan salat. Akan tetapi pada kondisi tertentu seperti adanya hajat, maka menggunakan masker hukumnya boleh. Pada kondisi merebaknya virus Covid-19 akhir-akhir ini, dapat dipahami bahwa menggunakan masker atau penutup mulut dan hidung ketika melaksanakan salat hukumnya boleh karena adanya hajat. Bahkan bisa meningkat kepada hukum dianjurkan jika seorang yang akan menghadiri salat jamaah dalam kondisi kurang sehat seperti demam, batuk atau flu. Hal ini diharapkan dapat mencegah tersebarnya virus Corona dalam masyarakat. jika seorang yang akan menghadiri salat jamaah dalam kondisi kurang sehat seperti demam, batuk atau flu. Hal ini diharapkan dapat mencegah tersebarnya virus Corona dalam masyarakat.

\section{KESIMPULAN}

Berdasarkan hasil pengkajian ini ditemukan bahwa edaran pemerintah berupa sistem lockdown dan Pembatasan Sosial Berskala Besar (PSBB) atau social distancing adalah merupakan syariat yang juga telah diamalkan oleh nabi Shallallahu 'Alaihi Wasallam bersama para sahabatnya radhiallahu 
'anhum kala wabah menimpa mereka. Demikian pula fatwa MUI berupa perintah tentang tempat ibadah harus disertai standar protokol kesehatan yang harus dipatuhi jamaah. Ketentuan hukum yang mesti diperhatikan baik oleh pengurus masjid atau jamaah ialah perenggangan saf ketika salat berjamaah. Dalam fatwa MUI disebutkan bahwa untuk mencegah penularan wabah covid-19, penerapan physical distancing saat shalat jamaah dengan cara merenggangkan saf hukumnya boleh, salatnya sah dan tidak kehilangan keutamaan berjemaah karena kondisi tersebut sebagai hajat syariyyah. Fatwa MUI itu juga mengatur soal penggunaan masker saat salat. Hukum asal menggunakan penutup mulut (masker) ketika salat adalah makruh tanzih yaitu makruh yang tidak membatalkan salat. Akan tetapi pada kondisi tertentu seperti adanya hajat, maka menggunakan masker hukumnya boleh. Bahkan bisa meningkat kepada hukum dianjurkan jika seorang yang akan menghadiri salat jamaah dalam kondisi kurang sehat seperti demam, batuk atau flu. Hal ini diharapkan dapat mencegah tersebarnya virus corona dalam masyarakat.

\section{UCAPAN TERIMA KASIH}

Penulis mengucapkan terimakasih kepada Fakultas Ekonomika dan Bisnis Universitas Muhammadiyah Pekajangan Pekalongan yang telah memberikan fasilitas dan dukungan kepada penulis untuk melakukan penelitian, terimakasih juga kepada semua pihak yang telah memberikan fasilitas dan bantuan sehinga terselesainya penulisan ini.

\section{REFERENSI}

Abidin, Firanda Andirja. Hukum Shalat Dengan Merenggangkan Shaff Hingga 2 Meter. Retrieved Juli $\quad 15, \quad 2020, \quad$ from https://ia802905.us.archive.org/26/items/hukums halatrenggang/hukum\%20shalat\%20renggang.p $\underline{\mathrm{df}}$

Al Khațțābī, Abū Sulaimān Ḥamd Ibn Muhammad ibn Ibrāhīm ibn Al Khațāb Al Bustî. 1932. Ma'àlim Al Sunan Syarh Sunan Abī Dāud edisi I. Volume 1. Halab: Al Maṭbaah AL Ilmiyyah.

Al Syairāzī, Ibrāhīm Ibn A'lī ibn Yūsuf. 1412H. Al Muhażżab Fi Fiqh al Imām Al Syāfi' '̄ Volume 1. Bairūt: Dār Al Kutub Al Ilmīyah.

Al-Asqolani, Ibnu Hajar. 1379 H. Fathul Bari syarah Shohih Al-Bukhari. AlQohirah Mesir: Maktabah as Salafiyah.
Arifin, T., Nuraeni, N., Mashudi, D., \& Saefudin, E. 2020. Proteksi diri saat pandemi COVID-19 berdasarkan hadits shahih.

As-Suyuti, Jalaluddin. 1432 H. Ad-Durr Al-Mantsur fi tafsiri al-ma'tsur. Beirut: Dar al-Fikr

Departemen Agama. 2004. Al Qur'an dan Terjemahannya. Surabaya: Mekar Surabaya.

Fagin, R. 1977. Multivalued dependencies and a new normal form for relational databases. ACM Transactions on Database Systems.

Hajjaj, Muslim ibn. 1412 H. Kitab Shohih Muslim. Beirut: Dar kutub al-ilmiyah.

Herlambang. 2020. Ini Fatwa MUI Terkait Salat Jumat Berjamaah di Masjid. Retrieved Juli 15, 2020 ,

from https://www.ayosemarang.com/read/2020/06/05/ $\underline{58169 / \text { new-normal-ini-fatwa-mui-terkait-salat }}$ jumat-berjamaah-di-masjid

Indriya, I. 2020. Konsep Tafakkur Dalam Alquran Dalam Menyikapi Coronavirus Covid19. SALAM: Jurnal Sosial dan Budaya Syar$i, 7(3)$.

Jabbar. 2020. Physical Distancing Dalam Hukum Islam Bisa Sunnah Bahkan Wajib. Retrieved Juli 15 , 2020 , from https://www.madaninews.id/10935/physicaldistancing-dalam-hukum-islam-bisa-sunnahbahkan-wajib.html

Jabbar. 2020a. Kiat Menyikapi Wabah Corona Sesuai Ajaran Islam. Retrieved Juli 15, 2020, from https://www.madaninews.id/10610/kiatmenyikapi-wabah-corona-sesuai-ajaranislam.html

Kementerian Agama RI. 2000. Al-Qur'an dan Terjemahnya. Retrieved Juli 15, 2020, from https://quran.kemenag.go.id/

Kementerian Agama RI. 2020. Surat Edaran Menteri Agama Nomor 6 Tahun 2020 tentang Panduan Ibadah Ramadan dan Idul Fitri 1 Syawal $1441 \mathrm{H}$. di Tengah Pandemi Covid-19, Pub. L. No. 6 (2020). Indonesia. Retrieved from https://kemenag.go.id/home/artikel/43328/surate daran-menteri-agama-nomor-6-tahun 2020tentang-panduan-ibadah-ramadan-dan-idulfitri1-syawal-1441h-di-tengah-pandemi-wabahcovid-19.

Martin, L. L., Levey, R., \& Cawley, J. 2012. The "New Normal" for Local Government. State and Local Government Review. 


\section{Jurnal Ilmiah Ekonomi Islam, 7(01), 2021, 402}

Muhammad Tahir, A. 2020. Nalar Agama dan Pandemi Covid-19. Prosiding Seminar Nasional Problematika Sosial Pandemi Covid-19 "Membangun Optimisme di Tengah Pandemi Covid-19" ISBN: 978-602-5722-33-2.

Mukharom, M., \& Aravik, H. 2020. Kebijakan Nabi Muhammad Saw Menangani Wabah Penyakit Menular dan Implementasinya dalam Konteks Penanggulangan Coronavirus Covid19. SALAM: Jurnal Sosial dan Budaya Syar$i, 7(3)$.

Murtadha Muthahhari. 2012. Memahami Pelajaran Tematis al-Qur'an Tafsir Tematis tentang Pengetahuan, Akidah, Akhlak dan Kehidupan Sehari-Hari. Jakarta: Sadra.

Pragholapati, A. 2020. New Normal "Indonesia" After Covid-19 Pandemic. Psyarxiv Preprint.

Rajab, A. J., Nurdin, M. S., \& Mubarak, H. 2020. Tinjauan Hukum Islam pada Edaran Pemerintah dan MUI dalam Menyikapi Wabah Covid19. BUSTANUL FUQAHA: Jurnal Bidang Hukum Islam, 1(2), 156-173.
Shihab, Muhammad Quraish. 2006. Lentera Hati: Kisah dan Hikmah Kehidupan, Cet.XXX; Bandung: Mizan.

Sumadi, S. (2020). Menakar Dampak Fenomena Pandemi Covid-19 Terhadap Perbankan Syariah. JURNAL HUKUM EKONOMI SYARIAH, 3(2), 145-162.

Syandri, S., \& Akbar, F. 2020. Penggunaan Masker Penutup Wajah Saat Salat Sebagai Langkah Pencegahan Wabah Coronavirus Covid19. SALAM: Jurnal Sosial dan Budaya Syari, 7(3), 261-268.

World Health Organization. 2020. Pertanyaan dan Jawaban Terkait Coronavirus. Retrieved Juli 15, 2020 , from https://www.who.int/indonesia/news/novelcoronavirus/qa-forpublic. 